\title{
Leukocyte Response and Phagocytic Activity in Common Carp, Cyprinus carpio Experimentally Infected With Virulent Aeromonas allosaccharophila
}

\author{
N. Shahi*, S.K. Mallik and D. Sarma \\ Directorate of Coldwater Fisheries Research (ICAR), Bhimtal 263 136, Nainital, (UK), India
}

\begin{abstract}
Total and differential leukocyte count, and the phagocytic activity in blood of common carp, Cyprinus carpio (Linnaeus, 1758), experimentally infected with virulent Aeromonas allosaccharophila was evaluated in this study. For experimental study, common carp fingerlings $(10.0 \pm 1.5 \mathrm{~g}$ Weight, $8.5 \pm 2.3$ $\mathrm{cm}$ Length) were divided into five groups in duplicates of un-injected fish, fish injected with sterile phosphate buffered saline (PBS), and fish injected with $4.2 \times 10^{4}, 1.9 \times 10^{6}$ and $7.3 \times 10^{8}$ colony forming units per milliliter (CFU ml-1) of suspension of A. allosaccharophila. Forty eight hours after infection, the total and differential leukocyte count and phagocytic activity of blood leukocytes of common carp was determined. The leukocyte, lymphocyte and monocyte count were significantly $(P<0.05)$ high in experimentally infected fishes, while no significant change in neutrophils number was observed. In fishes injected with $4.2 \times 10^{4}$,

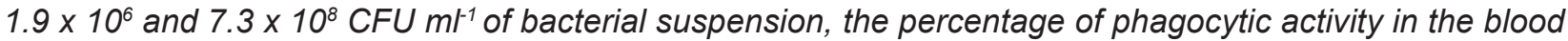
were 55.3, 54.7 and 58.2, respectively. The result suggests that, $A$. allosaccharophila could influence the leukocyte number and phagocytic activity of blood of common carp, which is an integral component of innate immune system of fish.
\end{abstract}

Keywords: Bacteria, Blood, Fish, Innate immunity, Phagocytosis.

\section{Introduction}

Innate immunological parameters are important indicator of fish health and its physiological status. It is one of the most important tool for fish disease diagnosis, and it's alter depend on the health condition of fish (Hrubec et al., 2000). Increase or decrease in neutrophil, monocyte and lymphocytes number may occur during microbial infections (Haney et al., 1992). Phagocytic activity is a cellular mediated nonspecific defense mechanism in fish, and may also vary according to its health status. Phagocytic activity of fish blood can be used as a significant nonspecific immunological indicator of immune-suppression in fish (Anderson, 1990). Increase in phagocytic activity in the spleen and blood of bacterial infected fish was reported earlier (Cai et al., 2004).

Outbreaks of bacterial diseases have been causing severe economic losses to fish farmers in India (Shahi and Mallik, 2013). Among bacterial diseases, motile aeromonad septicaemia (MAS) caused by Aeromonas spp. is commonly observed in freshwater cultured fish. Several Aeromonas such as $A$. hydrophila, A. sobria, $A$. bestiarum, and $A$. salmonicida are responsible for bacterial septicemia and ulcers in cultured fishes, worldwide. The outbreak of disease by Aeromonas spp. is a common problem in the intensive carp culture system, where stress is generated by higher stocking density and other adverse biotic and abiotic conditions. As carp farming system they also cause tail rot, fin rot, blood hemorrhage and epizootic ulcerative syndrome in rainbow trout culture practice of India (Shahi et al., 2013) The mortality caused by Aeromonads to cultured fishes can be over $95 \%$ under unfavorable condition (Zhan, 2004).

Aeromonas allosaccharophila is a mesophilic bacterium, first isolated from diseased elvers, Anguilla anguilla in Spain (Martinez-Murcia et al., 
2004). It is a rare and highly pathogenic bacterium, known to cause disease in fish, animals and humans (Saavedra et al., 2007). Since A. allosaccharophila is rarely encountered in fish diseases, its effect at immunological level is largely unknown. No published information is available from India about the effect of this bacterium on the leukocyte response and blood phagocytosis of cultured fishes. Thus, the aim of this study was to investigate the influence of $A$. allosaccharophila on leukocyte count and blood phagocytic activity of common carp, (Cyprinus carpio, L.) experimentally challenged with this pathogen.

\section{Materials and Methods}

\section{Experimental animal and acclimatization}

Fifty healthy common carp fingerlings (10.0 \pm $1.5 \mathrm{~g}$ Weight, $8.5 \pm 2.3 \mathrm{~cm}$ Length) were procured from a commercial fish farm of Uttarakhand, India for present investigation. Fish were divided into five groups, with ten fish in each group, maintained in ten tanks of 1000L capacity. Each tank had 5 fish (each group in duplicate). The health status of fish was ascertained by standard bacteriological techniques. Before experimental infection, fish were acclimatized for 15 days in wet laboratory of Directorate of Coldwater Fisheries Research (DCFR), Bhimtal and fed with commercial diet, ad libitum. During this period, the water quality was maintained as follows: temperature $16.0 \pm 0.6{ }^{\circ} \mathrm{C}, \mathrm{pH} 7.3 \pm 0.2$, conductivity $290.5-300.2 \mu \mathrm{s} \mathrm{cm}^{-1}$ and dissolved Oxygen $7.9 \pm 1.1 \mathrm{mg} \mathrm{l}^{-1}$.

\section{Bacterial culture}

The bacterium $A$. allosaccharophila was originally isolated from kidney of diseased rainbow trout, Oncorhynchus mykiss (Walbaum, 1792) and identified (accession number, 16S rRNA, KC816585; gyrB gene, KC865056) at fish bacteriology laboratory of DCFR, Bhimtal. This bacterium is maintained in bacterial freezing medium (AMRESCO) as stock at $-80{ }^{\circ} \mathrm{C}$.

\section{Preparation of bacterial inoculum \& its administration}

Bacterium was cultured overnight in tryptic soy broth (TSB, Difco) at $27{ }^{\circ} \mathrm{C}$. Culture was centrifuged at $10,000 \mathrm{rpm}$ for $5 \mathrm{~min}$, to pellet the cell. After removal of supernatant, the pellet was washed thrice in sterile phosphate buffered saline (PBS, pH 7.2). The concentration of the bacterial cell was determined and adjusted by taking OD at $540 \mathrm{~nm}$. Fishes were injected with $100 \mu \mathrm{l}$ of bacterial suspension in three different cell concentrations $4.2 \times 10^{4}, 1.9 \times 10^{6}$ and $7.3 \times 10^{8}$ colony forming unit (CFU) $\mathrm{ml}^{-1}$. The two other groups were un-injected fish and fish injected with $100 \mu \mathrm{l}$ of sterile PBS. All the injections were given in swim bladder, according to the method described earlier (Martins et al., 2004).

\section{Leukocytes count \& Phagocytic activity}

Forty eight hours after injection, the fish were anesthetized with tricaine methanesulphonate (MS-222) solution (4 mg ml-1). The blood was withdrawn from the caudal vein with a syringe rinsed with $2.5 \%$ EDTA solution and kept in 2.0 $\mathrm{ml}$ centrifuge tube coated with $20 \mu \mathrm{l}$ of $2.7 \%$ EDTA. The collected blood was used for total leukocyte count and differential leukocytes count (Martins et al., 2004). The blood was also used for evaluation of phagocytic activity of leukocytes. Total leukocytes were calculated by indirect methods as follows:

Leukocytes $\mu^{-1}=$ (Leucocyte number in the smear $\mathrm{x}$ erythrocyte number per microlitre)/ (2000 erythrocytes counted in the blood smear)

Leukocyte phagocytic function was carried out by the method described previously (Cai et al., 2004) with slight modifications. Five hundred microlitre of blood was taken in $2 \mathrm{ml}$ centrifuge

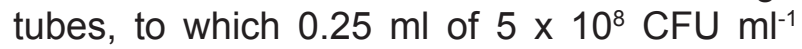
A. allosaccharophila culture was added. After mixing the tubes were incubated at $28{ }^{\circ} \mathrm{C}$ in a dry bath for $30 \mathrm{~min}$, with occasional shaking. Incubated tubes were centrifuged at $1500 \mathrm{rpm}$ for $5 \mathrm{~min}$. The supernatant was discarded, and the upper layer of the precipitate was used to make blood slides (three slides for each fish). 
The number of leukocytes that engulfed bacteria was calculated as follows:

Phagocytic percentage $(\%)=[100 \times$ (Phagocytotic leukocyte number)/ (Total leukocyte number)]

\section{Statistical Analysis}

The studied parameters were subjected to one way analysis of variance (ANOVA) and F-test $(P<0.05)$, and the averages to Tukey tests (SPSS version 19.0). Differences between experimental groups were expressed at a significant level of $P<0.05$.

\section{Results and Discussion}

The blood smear of injected common carp with different cell types is shown in Figure 1 and Figure 2.

The leukocyte count was higher $(P<0.05)$ in injected fishes compared to un-injected and fishes injected with PBS (Table 1). Significantly higher $(P<0.05)$ lymphocytes and monocytes numbers were observed in injected group than the control group. There was no significant change in the neutrophil number in experimental and control group. Higher $(P<0.05)$ percentage of

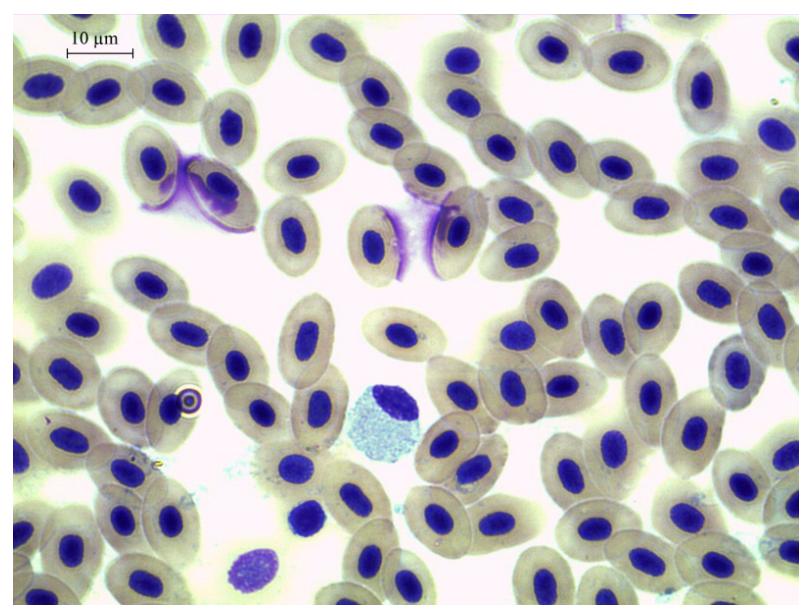

Fig. 1 Blood smear of injected common carp stained with May Grunwald stain showing macrophages and red blood cells. phagocytosis by leukocytes was observed in challenged groups (Table 1). The highest phagocytosis was found in fish injected with $7.3 \times 10^{8} \mathrm{CFU} \mathrm{ml} \mathrm{m}^{-1}$ of $A$. allosaccharophila.

Leukocyte count is an indicator of fish health status, due to its role in non-specific or innate immune response. An increase in the leukocyte count and its functions is most likely results in an enhancement of the non-specific defense, because macrophages and other phagocytic cells are the key cells of immune system. The present study describes the influence of $A$. allosaccharophila on leukocyte count and phagocytic function of common carp experimentally infected with the bacterium. Leukocyte number was significantly higher in experimentally

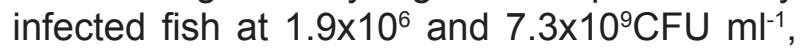
which indicates that $A$. allosaccharophila could induce the non specific innate defense mechanism of fish.

An increase in the number of circulating lymphocyte is observed in bacterium infected fish (Martins et al., 2009). Increased number of lymphocytes is an integral part of defense mechanism of any living organism. However, there are reports of lymphopenia under certain conditions, especially when fishes are intraperitoneally injected with bacterium (Lamas et al., 1994; Balfry et al., 1997). The lymphopenia in

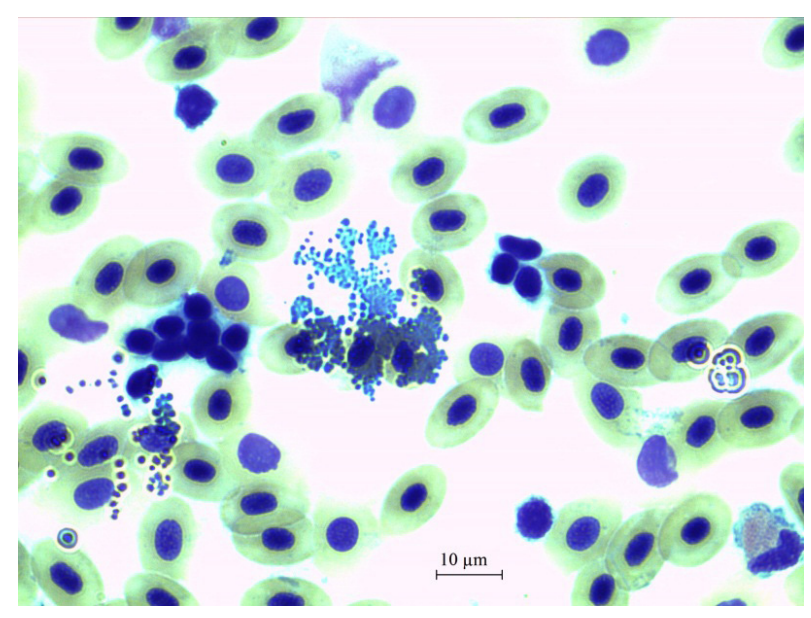

Fig. 2 Blood smear of injected common carp stained with May Grunwald stain showing blood platelets, red blood cells and macrophages. 
Table 1 Mean values of leukocytes, differential leukocyte and phagocytosis in common carp Cyprinus carpio in experimental groups: UI-Un-injected, PBS-Injected with phosphate buffered saline (PBS), and injected with three different doses $\left(4.2 \times 10^{4}, 1.9 \times 10^{6}\right.$ and $\left.7.3 \times 10^{8} \mathrm{CFU} \mathrm{ml}^{-1}\right)$ of Aeromonas allosaccharophila suspension in swim bladder.

\begin{tabular}{|c|c|c|c|c|c|}
\hline Treatments $^{*}$ & Leukocytes & Lymphocytes & Neutrophils & Monocytes & Phagocytosis (\%) \\
\hline & $\times 10^{3} \mu \mathrm{l}^{-1}$ & $\times 10^{3} \mu^{-1}$ & $\times 10^{3} \mu^{-1}$ & $\times 10^{3} \mu l^{-1}$ & \\
\hline UI & $15.6 \pm 2.9^{\mathrm{a}}$ & $13.3 \pm 1.4^{\mathrm{a}}$ & $5.6 \pm 1.2^{\mathrm{a}}$ & $8.6 \pm 1.2^{\mathrm{a}}$ & 0 \\
\hline PBS & $17.0 \pm 2.0^{\mathrm{a}}$ & $16.0 \pm 1.5^{\mathrm{a}}$ & $4.0 \pm 1.1^{\mathrm{a}}$ & $8.3 \pm 1.2^{\mathrm{a}}$ & 0 \\
\hline $4.2 \times 10^{4}$ & $26.6 \pm 1.8^{\mathrm{ab}}$ & $31.6 \pm 2.1^{\mathrm{b}}$ & $4.6 \pm 1.2^{\mathrm{a}}$ & $21.3 \pm 1.8^{\mathrm{b}}$ & $55.3 \pm 1.7^{\mathrm{a}}$ \\
\hline $1.9 \times 10^{6}$ & $33.6 \pm 2.3^{\mathrm{b}}$ & $35.6 \pm 2.7^{\mathrm{b}}$ & $5.0 \pm 0.5^{\mathrm{a}}$ & $23.3 \pm 1.7^{\mathrm{b}}$ & $54.7 \pm 5.2^{\mathrm{a}}$ \\
\hline $7.3 \times 10^{8}$ & $33.8 \pm 1.8^{\mathrm{b}}$ & $35.8 \pm 2.8^{\mathrm{b}}$ & $4.0 \pm 1.5^{\mathrm{a}}$ & $22.0 \pm 1.7^{\mathrm{b}}$ & $58.2 \pm 1.8^{\mathrm{a}}$ \\
\hline
\end{tabular}

"Each value in mean $( \pm S D)$ of 3 replicates

a, b, ab superscripts in the columns indicate significant difference among the treatment groups $(P<0.05)$.

intraperitoneal injected fishes might be caused by localized migration of lymphocytes to tissues.

Neutrophils are the first line of innate immune against infectious diseases. Apart from releasing various antimicrobial molecules, neutrophils also release neutrophil extracellular traps (NETs) for the containment of infection. Activated neutrophils provide signals for the activation and maturation of macrophages as well as dendritic cells. Neutrophils are also involved in the regulation of T-cell immune response against various pathogens. The number of neutrophils in fish injected with bacterium are not significantly different from the un-injected and PBS injected fish, which is in concurrence with the earlier finding (Ranzani-Paiva et al., 2004), while few other researchers found significant increase in the number of neutrophils and monocytes after bacterial infections (Garcia et al., 2007). In this study, monocytes were higher in injected fish in comparison to control fish.

Phagocytosis is one of the important processes in poikilothermic animals because it is the process that is least influenced by temperature (Blazer, 1991; Lange and Magnadottir, 2003). Phagocytic cells are the important cellular components of the innate immune system of fish (MacArthur and Fletcher, 1985), and their phagocytic activity is a defence mechanism, which is an important characteristic of the non specific immune system. The main cells involved in phagocytosis in fish are neutrophils and macrophages (Secombes and Fletcher, 1994). In this study the higher percentage of phagocytosis by leukocytes was observed in challenged groups (Table 1), as well as the highest phagocytosis was found in fish injected with $7.3 \times 10^{8} \mathrm{CFU} \mathrm{ml}{ }^{-1}$ of bacterium.

A. allosaccharophila is a rare bacterium, known to cause disease in fish. However, so far there are no reports of the effect of this bacterium on innate immune cells of carps. The results showed that, there is significant difference in some of the studied immune related blood parameters of common carp, experimentally challenged by $A$. allosaccharophila, which indicates that this virulent bacterium could induce the migration of immune cells. Future studies are needed to know the effect of this bacterium on hematological parameters of carp as well as antimicrobial activity of the serum.

\section{Acknowledgements}

The authors are thankful to the Director, Directorate of Coldwater Fisheries Research (DCFR), Bhimtal, India for providing necessary facilities and financial assistance to carry out the present work. 


\section{References}

Anderson, D. P. (1990) Immunological indicators: effects of environmental stress on immune protection and disease outbreaks. Am. fisheries Society symposium., 8, 38-41.

Balfry, S. K., Shariff, M. and Iwama, G. K. (1997) Strain differences in non-specific immunity of tilapia Oreochromis niloticus following challenge with Vibrio parahaemolyticus. Dis.of Aquat. Organ., 30, 77-81.

Blazer, V. S. (1991) Piscine macrophage function and nutritional influences: A review. J. Aquat. Anim. Health., 3, 77-86.

Cai, W.Q., Li, S.F. and Ma, J. Y. (2004) Diseases resistance of Nile tilapia (Oreochromis niloticus), blue tilapia (Oreochromis aureus) and their hybrid (female Nile tilapia x male blue tilapia) to Aeromonas sobria. Aquaculture., 229,79-87.

Garcia, F., Pilarski, F., Onaka, E.M., Moraes, F. R. and Martins, M. L. (2007) Hematology of Piaractus mesopotamicus fed diets supplemented with vitamins $\mathrm{C}$ and $\mathrm{E}$, challenged by Aeromonas hydrophila. Aquaculture., 271, 39-46.

Haney, D. C., Hursh, D. A., Mix, M. C. and Winton, J. R. (1992) Physiological and haematological changes in chum salmon artificially infected with erythrocytic necrosis virus. J. Aquat. Anim. Health., 4, 48-57.

Hrubec, T. C., Cardinale, J. L. and Smith, S. A. (2000) Hematology and plasma chemistry reference intervals for cultured tilapia (Oreochromis hybrid). Vet. Clin. Pathol., 29, 7-12.

Lamas, J., Santos, Y., Bruno, D. W., Toranzo, A. E. and Anadon, R. (1994) Non-specific cellular responses of rainbow trout Vibrio anguillarum and its extracellular products. J. Fish Biol., 5, 839-844.

Lange, S. and Magnadottir, B. (2003) Spontaneous haemolytic activity of Atlantic halibut (Hippoglossus hippoglossus L.) and sea bass (Dicentrarchus labrax) serum. Comp. Biochem. Physiol., 136, 99-106.

MacArthur, J. I. and Fletcher, T. C. (1985) Phagocytosis in fish. In: Manning MJ, Tatner MF (eds) Fish. Physiol., pp. 29-36. Academic Press, London.
Martínez-Murcia, A. J., Esteve, C., Garay, E. and Collins, M. D. (2004) A. allosaccharophila sp. nov., a new mesophilic member of the genus Aeromonas. FEMS Microbiol. Lett., 91, 199-106.

Martins, M. L., Nomura, D. T., Myiazaki, D. M. Y., Pilarsky, F., Ribeiro, K. and Castro, M.P. (2004) Physiological and haematological response of Oreochromis niloticus (Osteichthyes: Cichlidae) exposed to single and consecutive stress of capture. Acta. Sci. Anim. Sci., 26, 449-456.

Martins, M. L., Vieira, F. P., Jerônimo, G. T., Mourino, J. L. P. and Dotta, G. (2009) Leukocyte response and phagocytic activity in Nile tilapia experimentally infected with Enterococcus sp. Fish Physiol. Biochem., 35, 219-222.

Ranzani-Paiva, M. J. T., Ishikawa, C.M., Eiras, A. C. and Silveira, V. R. (2004) Effects of an experimental challenge with Mycobacterium marinum on the blood parameters of Nile Tilapia, Oreochromis niloticus (Linnaeus, 1757). Braz. Arch. Biol. Techn., 47, 945-953.

Saavedra, M. J., Perea, V., Fontes, M. C., Martins, C. and Martínez-Murcia, A. (2007) Phylogenetic identification of Aeromonas strains isolated from carcasses of pig as new members of the species Aeromonas allosaccharophila. A. Van Leeuw., 91, 159-167.

Secombes, C. J. and Fletcher, T. C. (1994) The role of phagocytes in the protective mechanisms of fish. Annu. Rev. Fish Dis., 2, 53-61.

Shahi, N. and Mallik, S. K. (2013) Recovery of Pseudomonas koreensis from eye lesions in golden mahseer, Tor putitora (Hamilton,1822) in Uttarakhand, India. J. Fish Dis, doi:10.1111/jfd.12126.

Shahi, N., Mallik, S. K., Sahoo, M. and Das, P. (2013) Biological characteristics and pathogenicity of a virulent Aeromonas hydrophila associated with ulcerative syndrome in farmed rainbow trout, Oncorhynchus mykiss (Walbaum), in India. Isr. J. Aquac. Bamidgeh, IJA 65.2013.926, 11 pages.

Zhan, W. B. (2004) Diseases of aquatic animals. China Agriculture Press: Beijing. 